\title{
An Overview of Dismissal of Managerial Employees for Breach of Fiduciary Duties
}

\author{
Konanani Happy Raligilia \\ Kola O. Odeku \\ Faculty of Management and Law, School of Law, \\ University of Limpopo, South Africa \\ Email:raligilia@gmail.com
}

\author{
Doi:10.5901/mjss.2013.v4n13p809
}

\begin{abstract}
Directors and other senior managers stand in fiduciary relationships to the company they work for and have the responsbility and duty to ensure that they do everything possible to act in good faith toward the company and make sure that they do not compromise their positions which might result in conflict of interest. However, should they breach thier fiduciary duties in whatever way, this will amount to breach of trust which may lead to criminal prosecution and dismissal from the company. With regard to their civil responsibilities, they will be made to restore or return the proceeds from the breach of trust. This paper examines the nature and scope of the implied terms of trust and confidence of managerial employees in the workplace. The paper highlights the importance of fiduciary relationships with regard to implied terms of loyalty, good faith and discharge of duty in the best interest of the company by responsible senior managers and directors. The paper analyses consequences of breach of fiduciary duty, obligation and trust by emphasising that the erring employee would be put through disciplinary processes which might lead to termination of employment or outright dismissal.
\end{abstract}

Keywords: Managerial employees, Fiduciary relationship, Breach of trust and confidence, Conflict of interest, Workplace

\section{Introduction}

A manager or an executive employee will be in breach of fiduciary relationship if he or she is not loyal to the establishment or acts contrary to the rules, regulations, mission, vision and policy of the company (Hazen and Hazen 2011). Those occupying managerial positions are expected to deliver based on the company vision and mission (Coulson-Thomas 1992). Diviation from this is considered as a breach of the implied term of trust, confidence and fiduciary obligations (Boyer 1983) and there are consequences.

However, in South Africa, any decision to be taken against an erring manager should conform and comply with the provisions of the Labour Relations Act 66 of 1995 otherwise such decision, for example, if it leads to the termination of the employment without due process, will amount to unfair dismissal (McDermott and Berkeley 1996). Consequent upon this, a managerial employee should conduct a self-evaluation based on his work experience and assess whether he is in line with and meets the standards set by the employer (Jensen and Raver 2012). With regard to an employee performing a distinct job that requires a degree of professional expertise of an extremely high standard, if there is slightest deviation from the set standards, this will result in grievous consequences which might lead to an outright dismissal depending on the outcome of the adjudication processes.

\section{Methodology}

The methodology for this study involved qualitative as opposed to quantitative method of research. The traditional method of citation, analysis of cases and other sources are the main scientific methods in legal scholarship, therefore, analysis of and engagement with contemporary literature relevant to the focus of the paper were. Other relevant statutory, legislative and policy frameworks were also thoroughly examined, analysed and applied to solve the problem of breach of trust, fiduciary obligations and confidence by managerial employees and directors in the workplace.

\section{Objective}

The objective of this paper is to show that irrespective of the title of an employee in a work place, in so far as such 
employee is exercising and discharging manegerial responsibility to the extent of having power to hire and fire and also access trade secrets of the company by virtue of his position, the employee is considered to stand in a fiduciary relationship to the company and he is not expected to do anything that will be in conflict of his duty or jeopardise the interest of the employer and the company. If he acts contrary to the interest of the company, the employee will be in breach of the fiduciary relationship and duty. There are consequences for this, the employee will be held accounable for any wrong doing.

\section{Literature Review}

According to the International Labour Organisation, managerial employee means an individual whose work has managerial responsibilities and who works under a contract of employment (ILO, 2008). In South Africa, the Basic Conditions of Employment Act 75 of 1997 defines senior managerial employee as an employee who has the authority to hire, discipline and dismiss employees and to represent the employer internally and externally. However, Woloschuk (2013) indicates that relationship between managerial employees and directors is often based on their understanding of their authority. Woloschuk (2013) provides distinction between managerial and director employees by indicating that managerial employees take responsibility for ensuring that the work is done, while directors have the power and authority to direct the actions of the subordinate who is accountable for carrying out certain duties.

Smith (2012) asserts that a senior managerial employee is under a fiduciary duty and relied on the the case of Augut Incorporation versus Aegis, Incorporation 409 Mass. 165, 172-73 (1991) to support this assertion. The employee in this case, occupies an important position and empowerers to run the company. In the process, he accessed and acquired a lot of information and trade secrets of the company. Thereafter, he decided to join a rival-competitor company and asked other employees to join the new company. Smith (2012) said that the Court invoked in favour of the previous employer the common principle that a top managerial employee may not solicit the departure of employees to work for a competitor and Judge Wilkins held at page 176 that:

The rule is most clearly applicable if the supervisor-manager, as a corporate pied piper, leads all his employer's employees away, thus destroying the employer's entire business Although Greenspan's solicitation was directed only at certain key managerial personnel, his duty to maintain at least adequate managerial personnel forbade him, while still general manager of his former employer, from seeking to draw key managers away to a competitor.

According to Brodie (2010), one of the current controversies concerning the law of the employment contract is whether the contract gives rise to a fiduciary relationship and, to the extent that it does not, whether it should. The terms fiduciary duty and obligation were best illustrated in Attorney- General versus Blake (1998) where Lord Woolf held at paragraph 16 that:

The core obligation of a fiduciary of this kind is the obligation of loyalty. The employer is entitled to the single-minded loyalty of his employee. The employee must act in good faith; he must not make a profit out of his trust; he must not place himself in a position where his duty and his interest may conflict; he may not act for his own benefit or the benefit of a third party without the informed consent of his employer.

The relationship between the terms fiduciary duty and obligation were further emphasised by Brodie (2010) who suggests that the obligation appears to be highly continuous to a fiduciary obligation and as such the obligation to act in the best interest of an employer at all times is particularly significant to the trust in a working relationship.

While the implied term of trust and confidence imposes obligation on both employers and employees, its most significant consequence lies in the breach of trust by the manager who is described as the corollary of the employee's duties to co-operate and to demonstrate fidelity and good faith (Blair and Stout 2001). Breach of trust and confidence requires, in the words of Lord Steyn in Malik versus Bank of Credit \& Commerce International, In liquidation (1997) United Kingdom House of Lord (UKHL) 23 at para 45 that a director should not:

without reasonable and proper cause, conduct itself in a manner calculated and likely to destroy or seriously damage the relationship of confidence and trust between employer and employee.

On the issue of loyalty to the company, Shaw and Graham (2007) observe that employees' duty of loyalty to their employers finds its source in the common law. They also asserted that an employee has a duty to act solely for the benefit of the company when engaging in any conduct that relates to the employment (Shaw and Graham 2007). 
According to Hamilton (2004), people in positions of trust or fiduciary relationship such as officers, directors, highlevel employees of a corporation or business, agents and brokers owe certain duties to their principals or employers. Smith (2012) states that fiduciary relationships which are by their very nature relationships of good faith, may involve a variety of obligations depending on the exact circumstances. Smith's position was supported by Kiri (2007) who argued that breach of trust or fiduciary duty can often represent the means by which a victim of the wrongdoing is best able to recover his loss, as the principal wrongdoer will often be untraceable or financially unable to satisfy any claim.

While the origins of the South African fiduciary duty evolve from the Roman-Dutch law, the duty of care originated in English tort law (Jones, 2007). In the course of analysis, this paper makes a distinction between issues surrounding consequences of breach of a director's fiduciary duties and those for breach of the duties of care and skill, although situations may arise where these overlap (Jones, 2007).

Jurisprudence from court indicates that good faith has long been equated with honesty; although an employment law case, Street versus Derbyshire Unemployed Workers' Centre (2004) seems to suggest that honesty is not enough and some purity of motive is required. This, although not necessarily increasing the onus on directors, is indicative of the courts' gradual shift toward imposing more stringent duties of good faith generally.

Another key case in this area is Fassihi versus Item Software (UK) Ltd (2004) in which the Court of Appeal held that the director owed a duty to confess his own misconduct to the company. In this case, Mr Fassihi, had set up a competing business and attempted to secure a lucrative contract from an existing customer of the company. The Court decided that Mr Fassihi had acted in breach of his fiduciary duty to act in good faith by failing to disclose his personal misconduct and conflict of interests. The consequence is that he had to account to the company for the profit he had made. In the same vein, Taylor (2011) accentuates that a director stands from the time of his appointment or, if not formally appointed, from the time he starts to act as such in a fiduciary relationship to the company, which arises from the purpose for which a director is entrusted with his office and for which he and his co-directors are entrusted with their powers to manage the affairs of the company. Hampton and Pace (1996) indicate that directors' fiduciary duties confer a statutory power and duty on them to manage the business of the company. This power comes from a statute and not the Memorandum of Incorporation of the company, so it is subject to shareholder control to a lesser extent than before (Taylor, 2011).

According to Shiu (2011), due to the element of dishonesty, cases of fraud or bribery are sometimes treated as consequences in cases in which fiduciary obligations will be imposed upon the managerial employee. Alternatively a managerial employee may be dismissed and may also be subjected to civil liabilities in which case the employer will be claiming damages against the employee (McConnico and Hargrove 2009). Depending on the responsibility being discharged or expected to be discharged, an employee who occupies a very senior position such as director or senior manager will be held fiduciary liable for conducting himself in a manner that jeopardise or in conflict with the day to day running of the company (Fishman, 1986). Consequently, while it is imperative that a director has a fiduciary obligtion to the company, as it has been canvassed in the case of Augut Incorporation versus Aegis, Incorporation 409 Mass. 165, 172-73 (1991), all manegerial employees are equally in fiduciary relationship to the company and therefore, have fiduciary obligations to the company during and after their employment with the company (Weinrib, 1975).

Smith's (2012) work provides a very useful insight on the inherent common law fiduciary duty and obligation of an employee to the employer irrespective of the nature of contract of employment signed between the two parties. Relying on the decision in the case of Chelsea Industrial Incorporation versus Gaffney, 389 Mass. 1, 11 (1983), she asserted that "Employees occupying positions of trust and confidence owe a duty of loyalty to their employer and must protect the interests of the employer." This duty continues even if the employee has left the former employer (Cotter, 1996). The employee is expected to desist from disclosing or misusing any knowledge or information or trust regarding the trade secret of the former employer (Steidman, 1962).

Pursuant to the backdrop of who should be held responsible for breach of fiduciary duty, Woloschuk (2013) description is apt "a person in a management position might be called a manager, a supervisor, a director, a coordinator or some other label that identifies him as a person with authority to make decisions." This list is not exhaustive. Hence anyone who has access to the company's trade secrets and also wield enormous and important power and position of authority will also be in breach of fiduciary duty if he acts in bad faith (Wedderburn, 1985).

The essence of this is to ensure that the fiduciary does not allow his interest to conflict with that of the employer (Anderson, 1977). Therefore, the fiduciary must not make a profit from his position (Sealy, 1962). This assertion has reverberated through numerous decisions handed down by the courts. The reason why the courts continue to hold this position is to dislodge the fiduciary from accruing illicit gains and profits (Sirodoeva-Paxson, 1998). This is the reason why the courts continue to rule that the wrongfully acquired money should be returned and be paid back to the employer (Weinrib, 1975). 


\section{Fiduacuary Obligation of the Managerial Employees}

One of the features of corporate directorship and responsibility is that a managerial employee is subject to certain fiduciary obligations (Dodd, 1935). In the workplace, directors and senior managers who have been entrusted with the responsibility to run the company are under the implied terms that they will be loyal and be of good faith when exercising their powers in the performance of their duties and they are under the obligation to do this in the best interest of the company (Ryan, 1991). This doctrine is deeply entrenched to the extent that Laskin J (as he then was) observed in the case of Canadian Aero Services versus O'Malley, 40 DLR (3d) 371 SCC (1973) that:

[T]he general standards of loyalty, good faith and avoidance of a conflict of duty and self-interest to which the conduct of a director or senior officer must conform, must be tested in each case by any factors which it would be reckless to attempt to enumerate exhaustively...Descending from the generality, the fiduciary relationship goes at least this far; a director or senior officer...is precluded from obtaining for himself either secretly or without approval of the company (which would have been properly manifested upon full disclosure of the facts), any property or business advantage either belonging to the company or for which it has been negotiating; and especially is this so where the director or officer is a participant in the negotiation on behalf of the company.

It has also been observed by Gibbs $\mathrm{CJ}$ in the High Court of Australia in the case of HospitalProducts Ltd versus United States Surgical Corporation (1984) that:

I doubt if it is fruitful to attempt to make a general statement of the circumstances in which a fiduciary relationship will be found to exist. Fiduciary relations are of different types, carrying different obligations ... and a test which might appropriate to determine whether a fiduciary relationship existed for one purpose might be quite inappropriate for another purpose.

Applying the principles enunciated in the quotations above, the all-encompassing fiduciary doctrine includes the director's duties to exercise care and skill, independent discretion; to act under available powers; not to improperly compete with the company; to account for secret profits; to avoid conflict of interests and duty; as well as, to disclose interest in a contract with the company (Purslowe, 2011).

Levenstein (2011) states that section 76 of the New Companies Act 71 of 2008 of South Africa addresses the standard of conduct expected from directors. Indeed section 76(3) states that a director of a company, when acting in that capacity, must exercise the powers and perform the functions of a director in good faith and for a proper purpose in the best interests of the company and with the degree of care, skill and diligence that may reasonably be expected of a person; carrying out the same functions in relation to the company as those carried out by that director and having the general knowledge, skill and experience of that director (Levenstein, 2011). Similarly section 76(4) states that in respect of any particular matter arising in the exercise of the powers or the performance of the functions of a director, a particular company director would have satisfied the obligations set out in section 76(3), if the director has taken reasonably diligent steps to become informed about the matter.

\section{Misrepresentation by the Managerial Employees to the Prospective Employer}

Although the general principle is that there is no duty on a prospective employee to disclose prejudicial information from his past to the future employer, however such duty may arise where the non-disclosure of information amounts to fraud (Grogan 2000: 125). At times, in a desperate bid to secure a job, managerial employees might misrepresent their qualifications, experiences or previous remunerations in their applications for employment or in the course of a preemployment interview (Merges, 1999). Schooling (2002), writing on pre-employment misrepresentation observes that:

Although it is possible that the situation could be dealt with in terms of the principles applicable to incapacity (if, for example, the employee has misrepresented that he has an accounting qualification, and that fact does render him incapable of performing his job to the required standards), the majority of these case are dealt with as a species of misconduct. Our courts generally accept that it is appropriate for an employer to enquire about an employee's employment history and conduct prior to taking up the position, and acknowledge that such facts often have a bearing on why an employer employs such a person in its organisation. In the event of material information coming to the attention of the employer, subsequent conclusion of the contract of employment, either because the employee has misrepresented himself or failed to disclose such information, the employer may convene a disciplinary inquiry on this basis. 
The fact that the employee has performed satisfactorily with the current employer prior to the discovery of preemployment misrepresentation will not bar the employer from instituting disciplinary action as enunciated in the cases of Auret versus Eskom Pension \& Provident Fund (1996) 7 BLLR 838 (IC) and Ndlovu versus Transnet t/a Portnet (1997) 7 BLR 887 (IC). In Transport and Allied Workers Union of South Africa obo Louw versus Volkswagen (Pty) Ltd (2003) 4 BALR 493 (CCMA), where the commissioner found that even though there is no employment relationship in existence at the time when the managerial employee makes the misrepresentation, the employer was entitled to dismiss him. In the present case the employee had substantially overstated the salary he earned in his previous employment and was appointed in a more senior position by his employer as a consequence. The arbitrating commissioner upheld his dismissal pursuant to a disciplinary inquiry on the basis that his misrepresentation during his interview and the continued lies regarding his earnings during the course of his employment had clearly rendered the trust relationship intolerable.

With regard to an applicant's suitability for employment, it is for the employer to ask the questions rather than for the applicant to volunteer information which may harm his prospects - unless his silence amounts to fraud. If the question is asked and a deliberately false answer given, then bad faith is established (Caisley, 2008). But dismissal may still not be justified if the matter is trivial or the employee's merits proved by subsequent good service.

\section{Failure to Disclose Material Facts}

According to Gibbs (2012), failure to disclose is a legal term used to refer to when a person or company conceals or omits important information. Gibbs went further to give a broader definition of material fact as a fact which, if known, would have affected the judgment of one or more of the parties to a transaction (Gibbs, 2012). For example there is a fair chance that a job seeker has left the employment of the former employer on bad terms and whatever the circumstances, the applicant is faced with the difficulty that volunteering such information could harm the prospects of getting a new job (Truter, 2011).

The employer's recourse to dismissal is less certain when the management employee has not actively misled the employer with his misrepresentations, but has simply failed to bring certain facts to the employer's attention (Schmall, 1999). As a general rule, a prospective employee is not obliged to disclose potentially prejudicial information to his employer (Fortney, 2009). In terms of the normal contractual principles of the common law, such a duty will only arise where there is a special relationship between the parties and the one party knows of the other's ignorance of material facts (Millner, 1957).

Grogan (2000: 137) notes that "an employee is obliged to disclose prior misconduct only if such misconduct has a bearing on the relationship to be forged with the new employer." He further states that:

Such a duty may arise where the non-disclosure amounts to fraud. In the present context, non-disclosure will be deemed fraudulent where the past misconduct would render the prospective employee totally unfit for the employment offered.

This will invariably depend on factors such as the nature of the position held by the employee and the nature of the misconduct committed by the employee (Okpaluba, 1999). In South African Commercial, Catering and Allied Workers Union obo Waterson versus JDG Trading (Pty) Ltd 3 BALR 353 (IMSSA) (1999) the employee applied for a position as a bookkeeper, knowing that he would work with money in the debtor's department, and had failed to disclose his previous convictions for armed robbery and theft. The arbitrator held that:

Considering his work environment and the degree of trust necessary, I am of the opinion that his non-disclosure of that information amounted to fraud. He must have known that that information would render him unsuitable for the position and, by means of omission, failed to disclose a material fact.

In Hoch versus Mustek Electronics (Pty) Ltd 3 BALR 353 (IMSSA) (1999) the company discovered some years after the applicant's appointment that she did not possess the qualifications she claimed to have when she was employed. Ms Hoch was dismissed after a disciplinary inquiry and appealed against her dismissal on the grounds of having misrepresented her qualifications. The company conceded that the diplomas in question were not indispensable to the adequate performance of Ms Hoch's work, but contended that, had it been known that she had misrepresented her qualifications; she would not have been appointed because the company places a premium on honesty.

The Labour Court found that Ms Hoch did not possess formal qualifications in either accounting or teaching, as she had claimed, but had merely completed a secretarial course in which one of the subjects had been accounting. Since she had persisted with her claim that she possessed the diplomas, once during the course of her employment and, again, in 
her disciplinary and appeal hearing, it could not be said that she had merely made an error of judgement. Even though Ms Hoch was an employee of long standing and the disputed qualifications were not directly relevant to her work, the company justifiably considered her dishonesty to be serious enough to have irreparably damaged the trust relationship. The court held that an employer has a prerogative to set standards of conduct for its employees and to decide the proper sanction if that standard is transgressed. The application was dismissed.

It should be noted that there is as yet no case law to indicate when the employee's failure to disclose information of a personal nature, for example, his ill-health or financial status, may constitute material disclosure, which may justify dismissal (Basson, 2002). Indeed, the court has held in the case of Spijkerman versus ABSA Bank Ltd 3 BLLR 287 (IC) (1997), that an employee's insolvency through no fault of his own does not justify termination of his employment as credit manager on operational grounds.

The employer must ensure, however, that such cases are treated consistently. A warning in this regard was sounded in National Union of Mineworkers in South Africa obo Engelbrecht versus Delta Motor Corporation 5 BALR 573 (CCMA) (1998) where an employee who was dismissed for failing to disclose a previous act of dishonesty in his job application form was reinstated by the arbitration commissioner, on the basis that the employer had previously condoned such misconduct by another employee.

In Mashava versus Cuzen and Woods Attorneys 21 ILJ 402 (LC) (2000), the Labour Court was unsympathetic to an employer's attempt to rely on the claim that the reason for the dismissal was not the employee's pregnancy but the employer's decision for offering her a position as candidate attorney without disclosing the fact that she was pregnant. The employer claimed that the trust required to offer her a position had been undermined. The court held that deceit could provide a ground for dismissal in instances when the underlying reason was the employees' pregnancy. The court stated that it understood the attitude of an employer when confronted with the situation where an employee had denied pregnancy to a member of staff and had failed to take her employer into her confidence. Nevertheless, this had to be measured against the right to privacy. Although a duty to inform the employer of her pregnancy might arise at a later stage, there was no immediate obligation on an employee to inform her employer that she is, or may be, pregnant. This applies even if the employee is employed on a probationary basis. The court found that the alleged deceit was no deceit at all, and that the real reason for her dismissal was her pregnancy or at least a reason related thereto.

The case underlines the importance of the relationship of trust that should exist in the employment context, particularly in positions of seniority (Truter, 2011). The consequence of failure to disclose is either a dismissal on the part of the employee or re-instatement on the part of the employer who unfairly dismissed the employee for such failure to disclose as in the case of Mashava versus Cuzen and Woods Attorneys 21 ILJ 402 (LC) (2000).

\section{Disclosure of Confidential Information}

According to Haney and Soohoo (2000), confidential information is often defined in employment agreements as anything the employee has seen, heard, learned or came across in the course of his or her employment, unless available to the public. Against this background, the employee may not use or divulge, for personal benefit, confidential information obtained as a result of the employment (Hannigan, 1929). In Pelunsky and Co versus Theron WLD 34 (1913), Theron, a clerk was employed by a certain livestock agent. While still in its service he copied a list of his employer's customers, as well as, the telegraphic code used by his employer while communicating with its clients. He then resigned from the job and set up his own business as a livestock agent and used the list and code to further his own business. The court held that there had been a breach of good faith on the part of Theron and that his former employer was entitled to damages. A very similar principle was formulated in Cooler Ventilation Co Ltd (SA) Ltd versus Liebenberg and another (1) SA 686 (W) (1967: 961) where the court had the following to say: "It seems to me that an employer is entitled to be protected from unfair competition, as it is called in American law, brought by confidential information of his business to a rival by an employee or ex-employee."

Generally, the above cases support the assertion that employees may not make use of information gained in the course of their employment in a manner inconsistent with their duty to further the employer's interests (O'Neill, 1992). However, employees may use general knowledge and skills acquired during employment with a particular employer once they leave the employment, even if their new employers will benefit from such knowledge and skills (Crouch, 1997).

However, Haney and Soohoo (2000) have argued that new employers need to be aware of the restrictions encumbering new executive employees, ensure that no documents or electronic information from a former employer is used, and make common sense judgements about the executive's immediate post-arrival activities. Hence, dismissal remains the main consequence of disclosure of confidential information while in the course of employment (Feldman, 1994). 


\section{Conclusion}

In a workplace, employees and, in particular, managerial employees are under all-encompassing fiduciary duties and obligations to ensure that; they exercise care and skill, independent but honest discretion, act within the ambit of the available powers, do not improperly compete with the company, account for secret profits, avoid conflict of interests and disclose interests in a contract with the company. Under the employment relationship, senior managerial employees have a greater obligation to refrain from engaging in conduct that is incompatible with the implied terms of trust and confidence. Consequently, directors therefore owe duties to the company and cannot divest themselves of nor be exempted from their fiduciary duties.

\section{Recommendations}

This paper demonstrates those who wield power and important positions have a duty to exercise reasonable care and skill when carrying out their duties by making well-informed decisions in the best interests of the company and the employees. In so doing, theys will avoid the consequences associated with breach of duty in the form of punitive measures. Mention must be made that breach of fiduciary duty is a civil matter on its own and not a criminal offense. However, where there is fraud or a criminal act, this will be resolved by investigation and, possibly, prosecution. In addressing the possible remedies for the breach of fiduciary duty, this paper recommends that the erring manager's assets should be up for forfeiture in order to recover ill-gotten money and assets fraudulently acquired. More importantly, the employer may recover for actual damages incurred and can also recover for punitive damages where the employer has proved malice or fraud.

\section{References}

Anderson AG 1977. Conflicts of Interest: Efficiency, Fairness and Corporate Structure, University of California Law Review, 25:738:747. Basson AC 2002. Pre-Employment Testing, South Africa Mercantile Law Journal, 14: 305-316.

Blair MMand Stout LA 2001. Trust, Trustworthiness, and the Behavioral Foundations of Corporate Law, University of Pennsylvania Law Review, 149(6): 1735 of 1735-1810.

Boyer B 1983. From Discretionary to Bureaucratic Justice. Michigan Law Review, 82: 971-982.

Brodie D 2010. The Employment Relationship and Fiduciary Obligations. Edinburgh Centre for Private Law workshop. From http://www.labourlawresearch.net/Portals/0/The\%20Employment\%20Relationship\%20and\%20Fiduciary\%200bligations.pdf (Retrieved 27 July, 2012).

Caisley KT 2008. Termination of employment: A best practice guide. Northcote, Aukland, New Zealand: CCH New Zealand Ltd.

Cotter T F 1996. Conflicting Interests in Trade Secrets, Florida Law Review, 48:591-603.

Coulson-Thomas C 1992. Strategic vision or strategic con?: Rhetoric or reality? Long Range Planning, 25(1):81-89.

Crouch C 1997. Skills-based Full Employment: the Latest Philosopher's Stone, British Journal of Industrial Relations, 35(3):367-391.

Dodd EM 1935. Is Effective Enforcement of the Fiduciary Duties of Corporate Managers Practicable? The University of Chicago Law Review, 2(2):194-207.

Feldman MJ 1994. Toward a Clearer Standard of Protectable Information: Trade Secrets and the Employment Relationship. High Technology Law Journal, 9:151-161.

Fishman J 1986. Standards of Conduct for Directors of Non-profit Corporations, Pace Law Review, 7:389-409.

Fortney SS 2009. Leaks, Lies, and the Moonlight: Fiduciary Duties of Associates to Their Law Firms, St. Mary's Law Journal, 41:595605.

Gibbs E 2012. Failure to Disclose is a form of Misrepresentation \& Fraud. From http://www.girardgibbs.com/failure-to-disclose/ (Retrieved 7 June, 2013).

Gordon D 2002. The Critical Resource Theory of Fiduciary Duty. Vanderbilt Law Review, 55:1399-1410.

Grogan J. 2000. Workplace Law $6^{\text {th }}$ edition . Juta \& Co Ltd publishers, Cape Town, South Africa.

Hamilton E 2004. Identifying Breaches of Fiduciary Duties. From http://www.hamiltonfirm.net/pdf/pub_fiduciaryduties.pdf (Retrieved 12 July, 2012).

Hampton BM, Pace HS 1996. Agency Powers and Fiduciary Duties under the Alabama Limited Liability Company Act: Suggestions for Future Reform. Alabama Law Review 48: 143-154.

Haney RP, Soohoo C 2000. The Dangers of Confidentiality Pacts. Covington \& Burling Company. From http://www.cov.com/files /publication/bcfe62c9-8443-47a7-bf08-d86ce0f2e8c3/presentation/publicationattachment/87bacf61-a7f1-410e-8e86-e7ad4563 d7c5/oid6364.pdf (Retrieved 2 June, 2013).

Hannigan JE 1929. The Implied Obligation of an Employee. University of Pennsylvania Law Review and American, 77(8): 970-980.

Hazen TL, Hazen LL 2011. Punctilios and Nonprofit Corporate Governance - A Comprehensive Look at Nonprofit Directors' Fiduciary Duties. University of Pennysylvenia Journal of Business Law, 14: 347-361. 
ILO. 2008. International Labour Organisation Database of Labour Legislation. From http://www.locarib.org.tt/projects/cariblex/cml 2.shtml (Retrieved 182 June, 2013).

Jensen JM, Raver JL 2012. Consequences for Employees' Organizational Citizenship and Counterproductive Work Behaviors, Group Organization Management, 37:(3) 308-346.

Jones E 2007. Directors' Duties: Negligence and the Business Judgment Rule (19). South African Mercantile Law Journal, 19: 326-336.

Kiri N 2007. Dishonest Assistance: The Latest Perspective from the Court of Appeal. Journal of International Banking Law and Regulation, 22(6): 305-317.

Levenstein E 2011. The New Companies Act, No. 71 Of 2008 : Reckless Trading and the Personal Liability of Directors. From http://www.mondaq.com/x/140688/Corporate+Company+Law/The+New+Companies+Act+No+71+Of+2008+Reckless+Trading+ And+The+Personal+Liability+Of+Directors (Retrieved 22 July, 2012).

McConnico S and Hargrove S 2009. Evaluating and Litigating Fiduciary Duty Claims. AustinBar.org. From http://www.austinbar.org lassets/pdfs/EPP_Fidiciary_Duty_Claims.PDF (Retrieved 24 June, 2013).

McDermott EP and Berkeley AE 1996. Alternative dispute resolution in the workplace: Concepts and techniques for human resource executives and their counsel,Quorum Books, Westport, USA.

Merges RP 1999. Law and Economics of Employee Inventions. Harvard Journal of Law \& Technology, 13: 1-9.

Millner, MA 1957. Fraudulent Non-Disclosure, South African Law Journal, 74:177-189.

Okpaluba C 1999. Employee's misconduct, employer's reasonableness and the law of unfair dismissal in Swaziland. The Comparative and International Law Journal of Southern Africa, 32(3): 386-405.

O'Neill TA 1992. Employees' Duty of Loyalty and the Corporate Constituency Debate. Connecticut Law Review, 25:681-692.

Purslowe R 2011. Decisions in the Twilight Zone of Insolvency - Should Directors Be Afforded a New Safe Harbour. University of Notre Dame Australia Law Review, 13:113-122.

Ryan PJ 1991. Strange Bedfellows: Corporate Fiduciaries and the General Law Compliance Obligation in Section 2.01(a) of the American Law Institute's Principles of Corporate Governance. Washington Law Review, 66: 413-423.

Schmall LA 1999. Keeping Employer Promises When Relational Incentives No Longer Pertain: Right Sizing and Employee Benefits. George Washington Law Review, 68: 276-287.

Schooling H 2002. Misrepresentation and an employee's failure to disclosure information to a prospective employer, Contemporary Labour Law, 13(1): 1-5.

Shaw JB and Graham BD, 2007. The Breach of the Duty of Loyalty: What Employers Can Do About it. From http://shawvalenza.com /publications.php?id=68 (Retrieved 17 July, 2012).

Sealy LS 1962. Fiduciary Relationships, The Cambridge Law Journal, 20(1): 69-81.

Shiu MY 2011. A Position of Trust? New Law Journal. Issue 7488. From http://www.newlawjournal.co.uk/nlj/content/position-trust (Retrieved 27 June, 2013).

Smith PA 2012. The employee's fiduciary duty to the employer and what to consider as you plan to leave. From http://pamsmithlaw.com/2012/08/07/the-employees-fiduciary-duty-to-the-employer-and-what-to-consider-as-you-plan-to-leave/ (Retrieved 27 June, 2013).

Sirodoeva-Paxson ON 1998. Judicial Removal of Directors: Denial of Directors' License to Steal or Shareholders' Freedom to Vote? Hastings Law Journal, 50(1): 70-84.

Steidman J C 1962. Trade Secrets, The Ohio State University Ohio State Law Journal, 23:4-9.

Taylor J 2011. Directors have increased responsibility towards companies: New Act. From http://www.polity.org.za/article/directors-haveincreased-responsibility-towards-companies-new-act-2011-11-04 (Retrieved 12 July, 2012).

Truter J 2011. Prospective Employee's Duty to Disclose Information. From http://www.labourwise.co.za/labour-articles/prospectiveemployees-duty-to-disclose-information (Retrieved 7 June, 2013).

Wedderburn L 1985. Trust, Corporation and the Worker, Osgoode Hall Law Journal, 23:203-214.

Weinrib EJ 1975. The fiduciary obligation, The University of Toronto Law Journal, 25(1):1-22.

Woloschuk C 2013. What's the Difference between Line and Staff Management? Suite101.com. From http://suite101.com/article/whatsthe-difference-between-line-and-staff-management-a293793 (Retrieved 26 June, 2013). 